\title{
Sinema ve Edebiyat İlişkisine Yöntemsel Bir Bakış
}

\author{
Süreyya Çakır*
}

$\ddot{O} z e t$

Tarih içinde sinema ve edebiyat ilişkisi, sinema ile diğer sanatlar arasındaki ilişkinin en kayda değer, en yaygın biçimlerinden biridir. Hem sinema dilinin oluşumunda hem de gelişiminde edebiyatın, özellikle romanın etkisi büyük olmuş; uyarlamalar içinde roman en önemli yeri tutmuştur. Edebiyat da özellikle biçimsel özellikler açısından sinemanın anlatım olanaklarından faydalanmıştır. Ancak bu karşılıklı ilişkinin değerlendirilmesinde yazınsal metne sadakate dayalı geleneksel uyarlama anlayışı ölçüt olarak alınmış, bu doğrultuda bu ilişkiye ve uyarlamalara genellikle olumsuz bir bakış hâkim olmuştur. Günümüzde son derece merkezi bir yerde duran uyarlamalara dair ikili karşıtlıkların sinırlılılarına dayanmayan ve daha geniş bir yorumlama alanı sunan bir yaklaşıma gereksinim var. Bu çalışmanın amacı kültürün tüm olasılıklarıla bağlantı kurma zeminine sahip olan Bakhtinyen perspektifikullanarak, uyarlamalara dair sadakate dayalı bakma biçiminin sınırlılıklarım aşan, daha kuşatıcı ve çok-katmanlı bir yaklaşım geliştirmeye çalışmaktır. Sadakat ile ilgili meseleleri gözden çıkarmadan lakin meseleyi çok yönlü ve bağlamsal bir eksende tartışmayı mümkün kılan Bakhtinyen metinlerarası diyalojik yaklaşım böyle bir bakma biçimini mümkün kılmaktadır. Genel olarak bu çalışmada, metinlerarası ilişkilere, özelinde sinema ve edebiyat ilişkisine ve onun en temel biçimi olan uyarlamalara dair bir yaklaşım geliştirme potansiyeli taşıyan bu yaklaşımın temel önermelerinin ve kavramlarnın sinema ve edebiyat ilişkisi açısından içerimleri üzerinde durulmaktadır.

Anahtar Sözcükler: edebiyat, sinema, Bakhtin, metinlerarası diyaloji

ORCID ID : 40-0002-1098-0212

E-mail : scakir@sakarya.edu.tr

DOI: $10.31122 /$ sinefilozofi.512804

Geliş Tarihi - Recieved: 15.01.2019

Kabul Tarihi - Accepted: 15.04.2019 


\title{
A Methodological View on the Relationship Between Film and Literature
}

\author{
Süreyya Çakır*
}

\begin{abstract}
The relation between literature and film through the history has been one of the most notable and common forms of the relationship between cinema and other arts. Literature, especially novel had great influence on the formation and development of film language and novel played an important role in literary film adaptations. Literature has also benefited from the expression possibilities of cinema in terms of formal features. However, in evaluating this mutual relationship, loyalty to literary texts has been taken as criterion by traditional adaptation understanding and in this respect this relationship and adaptations have generally been dominated by a negative outlook. Today there is a need for a more comprehensive approach that does not rely on the restrictions of dual oppositions of adaptations and offer a broader interpretation space. The main aim of this study is to develop more encompassing and multi-layered aspect on adaptations using Bakhtinyen perspective which has the basis of linking with all possibilities of culture and transcends the limitations of the discourse of loyalty and offers a more encompassing and multi-layered approach. The Bakhtinyen intertextual dialogic approach, which makes it possible to discuss the issue in a multidimensional and contextual axis without sacrificing loyaltyrelated issues, makes such a way of looking possible. In general, this study focuses on the implications of the basic propositions and concepts of this approach in terms of the relationship between cinema and literature, which has the potential to develop an approach to intertextual relations, in particular the relation between cinema and literature and adaptations that are its most basic form.
\end{abstract}

Keywords: film, literature, Bakhtin, intertextual dialogism

ORCID ID : 40-0002-1098-0212

E-mail : scakir@sakarya.edu.tr

DOI: 10.31122/ sinefilozofi.512804

Recieved - Geliş Tarihi: 15.01.2019

Accepted - Kabul Tarihi: 15.04.2019 


\section{Giriş}

Eski zamanlardan beri farklı anlatı biçimleri/türler arasında karşılıklı bir etkileşim olmuş; her yeni anlatım biçimi geçmiş çağların geleneklerinden, kültürel mirasından, anlatı biçimlerinden faydalanmıştır. Sinema da diğer sanatlarla ilişki içinde doğmuş ve gelişmiştir. Masal, çizgi roman, tiyatro, resim, fotoğraf, halk edebiyatı, roman sinemanın özellikle başlangıç evresinde etkilendiği öğeler arasındadır. Sinemanın "diğer sanatların reenkarnasyonu (yeniden doğumu) olarak ortaya çık[tı̆̆ını]" söyleyen Bazin (2000: 67) , onun evriminin, "diğer sanatların evriminin belirleyicilerinin bir finali görünümü içinde" olduğunu belirtir (2000: 65). Bunda, sinemanın yalnızca, en son ortaya çıkan sanat dalı olmasının değil, diğer sanat dallarıyla "kaynaşmaya yatkın" yapısının da payı vardır (Özön, 1964: 796). Wollen'ın da belirttiği gibi, “Tek bir öze dayalı, katışıksız sinema" diye bir şey söz konusu değildir (1989: 155). Sinema, doğası gereği diğer sanatlarla bağlantılı, melez bir sanattır; ancak sadece diğer sanatların bileşkesinden oluşan bir sentez değil, diğer sanatlardan aldıklarını kendi yapısı içinde özümseyip kendine mal eden bireşimsel bir sanattır. Bu nedenle Badiou, sinemanın ancak diğer sanatlarla bağlantısı içinde kavranabileceğini söyler: "Sinema çok özel bir anlamda yedinci sanattır. Diğer altı sanatla aynı düzlemde onlara eklenmez, onları ima eder, diğer sanatların artı bir'idir. Onlar üzerinde, onlardan hareketle, onları kendi kendilerinden eksilten bir hareketle iş görür." (2013: 94).

Lakin sinema diğer sanatlarla bu sıkı bağına karşın daha çok edebiyat ile karşılaştırılmıştır. Aslında tarihsel olarak çok da temelsiz değildir sinemanın sürekli olarak edebiyat ile kıyaslanması. Sinema kurmaca ve anlatısal özelliklerinden dolayı en çok edebiyat, özellikle roman ile daha sıkı bir ilişki/etkileşim içinde olmuştur (Taylan, 1994: 89). Sinemanın ortaya çıkışında yazınsal kültür öğeleri ciddi bir öneme sahip olmuş, sinema dilinin oluşumu kadar gelişiminde de romanın etkisi büyük olmuş, uyarlamalar içinde roman en önemli yeri tutmuştur (Özön, 1964: 798). İlk yıllarında tiyatro ve edebiyata sıkı sıkıya bağlı olan, ağırlıklı olarak sinemanın edebiyattan yararlandığı tek yönlü olarak gelişen bu ilişki, kısa zamanda çift yönlü bir nitelik kazanır. Modernist/Postmodernist itkiler ekseninde biçimsel, estetik ve auterist nitelikli etkileşimlerin yanı sıra, tecimsel saikler ve popüler ilgiler nedeniyle de süreklilik kazanır bu ilişki. Kimi zaman ticari, kimi zaman estetik kaygılarla, öykü ve söylem olanakları açısından film ve roman temas içinde olur; yazar ve yönetmenin kesişen yolları bugüne uzanır. Görüntü temelli sanat olan sinema ile sözcük temelli sanat olan edebiyat -özellikle roman- anlatım araçlarının farklılığı gibi biçim özelliklerini belirleyen sınırlamaların dışında, aynı çağın anlatı formları olmaları, "düşsel yaratı yakınlıkları" ve bir takım teknik ortaklıklar ve benzerlikler dolayısıyla karşılıklı etkileşim içinde olur. "Sinema neyi göstereceğini, bakışının konusunu seçerken roman alanına, roman da nasıl sergileyeceğini saptarken sinema tekniklerine yakınlaşır."(Aykın, 1983: 482) Hem kökensel özellikleri ve gelecek olasılıkları hem de aynı çağın anlatı formları olmaları açısından önem taşıyan, farklı nedenselliklerden kaynaklanan sinema ve roman ilişkisi, kimi zaman diyaloğa kimi zaman rekabete dayalı aşk ve nefret duyguları eşliğinde günümüze dek varlığını sürdürür.

Lakin, sinema ile edebiyat arasında günümüze dek devam eden bu ilişki, sinema ve edebiyat arasındaki yoğun ortaklık zeminine ve sanatsal iletişim açısından geniş bir imkân alanı olarak durmasına rağmen özellikle yazınsal uyarlamalar söz konusu olduğunda, genellikle olumsuz sonuçlar üreten bir mesele olarak karşımızda durmaktadır. Bu olumsuzlama, uyarlamalarda basitleştirmeye/popülerleştirmeye dayanan sorunlardan kaynaklandığı gibi, 
kaynak metne sadakati temel alan geleneksel uyarlama anlayışının hâkim bakış açısı ile de ilgilidir. Bu nedenle, meselenin ne olduğu ve ona nasıl yaklaşmak gerektiği üzerinde durmak önem taşımaktadır. Bu amaçla, sinema ile edebiyatı birbiri karşısında hakimiyet ilişkisi içinde konumlandıran uyarlama anlayışlarının varsayımları ve sınırlılıkları üzerinde durmak ve bunları aşmak üzere daha uzlaşmacı ve geniş ölçekli bir yaklaşım geliştirmek, bu sınırların aşılacağı bir imkân alanı olarak önümüzde durmaktadır.

\section{Sinema-Edebiyat İlişkisinde Ölçüt Meselesi}

Hem tarihsel açıdan hem de günümüzde son derece merkezi bir yerde duran sinemaedebiyat ilişkisinin en temel biçimi ve en önemli somutluk alanı olan uyarlamalar oldukça karmaşık ve çelişkilerle dolu bir mesele olarak karşımızda durmaktadır. Sinema ile edebiyat arasında günümüze dek devam eden ilişkinin, genellikle, "karşılıklı yarar ve birbirini besleyen bir diyalogdan ziyade bir rekabet ve mücadele ilişkisi olarak görül”düğünü söyler Stam (2005:4). Yazarla yönetmen arasında, yazınsal kültürle film kültürü veya iki ayrı dil sistematiği arasındaki çatışma ilişkisi olarak ele alınan bu ilişki; sözcük/imge, yazar/yönetmen gibi karşıtlıklar temelinde sinema veedebiyatı rakip olarakgören ikili düşünce biçiminin sınırlılıkları altında kalmıştır. Ayrıca bu mesele, karşılaştırmalı saygınlık meselelerini de beraberinde getirmiştir. Bu karşılaştırmada binyıllarca süren bir geleneğe sahip olan edebiyat, ortalama yüzyıllık bir geleneğe sahip olan sinema ile karşılaştırılmış; genellikle edebiyat gibi sözcük temelli sanatları sinema gibi görüntü temelli sanatların üzerinde konumlandıran geleneksel hiyerarşi tarafından edebiyat daha saygın, seçkin ve üstün olarak görülmüştür (Stam, 2014: 21, 223). Olumsuz sonuçlar üreten bir mesele olarak görülmesiyle bağlantılı olarak uyarlamalar genellikle olumsuzlanmıştır. Oysa edebiyatın kayıplarından ziyade kültürün kazanımları veya uyarlama ile bağlantılı kültürel meseleler üzerine düşünmek gerekir.

Bazin, sanat olarak sinema söz konusu olduğunda, estetik düzlemdeki etkileşimlerin -biçimsel ve avangard etkileşimler- zenginleştirici olduğunu, ayrıca endüstriyel bir olgu olarak sinemanın uyarlamalarla ilgili popülerleştirme ve basitleştirmeye dayanan kimi sorunları olsa da, uyarlamalardan kültürün ve edebiyatın bir şey kaybetmeyeceğini, tersine sinemanın gelişimine katkıda bulunacağını öne sürerek uyarlamaları savunur (1995: 124-125). Filmin görme/işitme gibi çeşitli duyuları bir araya getirme kapasitesinden ve kendinden önceki sanatları özümseyen birleşik bir dokuya sahip olmasından dolayı uyarlamalar, tüm bu farklı alanların iç içe geçtiği ilişkisel bir yapı oluşturur. Filmsel anlatının resmi, şiiri veya müziği içerebilme veya metaforik olarak bunların yol-yöntemlerini örnek alarak onları çağrıştırabilme özelliğinden dolayı uyarlamalar sanatsal referansları genişleterek sinemaya özgü gösterenlerin çokluğu avantajına sahip olabilir (Stam, 2005: 23-24). Ayrıca, film uyarlamaları, kaynak metnin alanını genişletir. Uyarlamalar basitçe daha üstün görülen kaynak metnin soluk bir taklidi değildir; yeni bir bağlama aktarılan "alıntıdır"; dolayısıyla kaçınılmaz olarak yeniden işlevlendirilir. Bu nedenle uyarlama, kaynak metnin anlamını ortadan kaldırmak yerine, onu Benjamin'in demokratik olarak bulduğu bir süreç içinde "yayar" (Ray, 2000:45). Benjamin şöyle söyler: "[T]eknik yolla yeniden üretim, özgün yapıtın kopyasını yapıtın aslı için düşünülemeyecek konumlara getirebilir. Her şeyden önce ister fotoğraf, ister plak aracılığıyla olsun, yapıtın izleyiciye gelmesini sağlar." Bunun yanı sıra, yeniden üretim tekniği, yeniden üretilmiş olanı çoğaltır ve günceller (1993: 49). Bu bakış açısı içinde uyarlamalar da bir bağlamda üretilmiş olanı başka bir bağlamda yeniden üretirken onun alanını genişletir, çoğaltır ve günceller. Örneğin, Feride Çiçekoğlu'nun 1986 yapımı Uçurtmayı 
Vurmasınlar romanından aynı adla uyarlanan film (1989) romana vurgu yapmıs, onun alanını genişletmiş, yaygınlaştırmıştır. Filmden sonra romanın baskı sayısı ile birlikte görünürlüğü artmış, daha çok okunmuştur. Nitekim herkese kendi düşsel tasarımlama olanağını sunarak onu daha çekici kılan yazının bu düşsel sorgulama olanağını daha fazla sayıda okura sunan filmin bu yaygınlaştırma işlevini filmin armağanı olarak gören ve bu nedenle beyazperdeye gönül borcu olduğunu söyleyen yazar Çiçekoğlu bu borcu şöyle gerekçelendirir: "Öykü, bir rastlantılar dizisi sonucu 1989'da film olmasaydı, Barış [öykünün ve filmin kahramanı] alçakgönüllü bir kitabın sayfaları arasından mırıl mırıl konuşmayı sürdürecekti; ta ki kitabın ilk ve tek basımı kim bilir kaç yıl içinde tükenene dek." (2016: 9) Dolayısıyla kaynak metnin alanını genişleten ve hayat içinde merkezi bir yerde duran uyarlamalar hakkında düşünce geliştirmek, bunun için de ikili karşıtlıklara dayanan bakma biçiminin sınırlılıklarını aşmak gereklidir.

Çok yönlü boyutlar taşıyan uyarlama meselesine farklı yaklaşımlar söz konusudur. Özellikle edebiyat çalışmaları alanı ile karakterize olan ve kaynak metne sadakati temel alan geleneksel uyarlama söylemi, uzun bir süre tek bakma biçimi olarak egemenliğini sürdürmüştür. Film sürekli olarak romana göre değerlendirilmiş, eleştirilerde ahlaki bir kavram olan sadakat ölçüt alınmış ve edebiyatın sinemaya üstünlüğü varsayımına dayanan ikili karşıtlara dayanan bakma biçimi hâkim olmuştur. Bu doğrultuda uyarlamalara bakış genellikle belli bir önyarg1 içermiş ve bu ilişki olumsuzlanmıştır. Bunun karşısında ise son yıllarda film çalışmalarının önem kazanmasıyla yükselişe geçen, metne sadakati sorunsallaştıran, özellikle Robert Stam'in uyarlama çalışmalarında kendini ortaya koyan bir diğer yaklaşım, kendine özgü ontolojik özelliklere sahip iki ayrı sanat dalı arasında sadakatin mümkün olmadığını, kaynak metin ile uyarlama metin arasında eşdeğerlik olmak zorunda olmadığını öne sürer. Stam, her ne kadar çoğu edebiyat uyarlamasının vasat veya yanlış yönlendirilmiş olduğu gerçeği önümüzde dursa da iki sanat arasındaki ilişkiye dair daha köklü ve bilinçsiz varsayımlar temelinde yükselen edebiyatın sinemaya üstün olduğu argümanına yaslanan ve bu nedenle filme ve uyarlamalara karşı olumsuz yargılar içeren geleneksel uyarlama söyleminin, uyarlamalarda kaynak metin olan edebiyatın kayıplarından ve belli uyarlamaların hatalı yorumlarından söz ettiğini ancak ne kazanıldığını ihmal ettiğini öne sürer (2005:3-4). Kaynak metne sadakatin mümkün ve hatta arzulanır bir şey olmadı̆̆ını iddia ederek sadakat söylemini eleştiren bu yaklaşımın son derece haklı gerekçeleri vardır. Bu çalışmada bu yaklaşıma yakın durulmakla birlikte bu bakma biçiminin de belli sıkıntıları vardır. Nitekim Metz, film çalışmaları alanının da filmik sistemlerin estetik üstünlüğü iddiasına dayanarak bir başka ikiliği yeniden ürettiğini öne sürer (2008: 210).

Sadakatsöylemi ileilgili tüm eleştirilerekarşın, uyarlama örneklerindekiuygulamalarda kaynak metne sadık uyarlama pratikleri ve metne sadakatin savunucuları varlığını sürdürmektedir. ${ }^{1}$ Uyarlama işlemi, çoğu zaman, kaynak metne şu veya bu ölçüde bağlı olarak

1 Roman uyarlamalarında kaynak metin ile ilişkide genellikle üç tutum gözlenmiştir: Ya kaynak metne birebir sadakat temel alınmış; veya tersi olarak kaynak metin sadece esin kaynağı olmuş, kaynak metnin değişikliğe uğratıldığı bir serbest uyarlama söz konusu olmuştur. Üçüncü olarak ise, kaynak metne birebir sadakatten ziyade, onun estetiğini film estetiğinin olanakları ölçüsünde yeniden üreten yaratıcı uyarlamalar gündeme gelmiştir. Uyarlamalarda kaynak metne birebir sadık kalındığı, Aykın'ın deyişiyle "Romanın sinemaya egemen kılındığı" ilk tutumda, kaynak metnin özellikleri öne çıkar. Sinemasal öğeler usçu ve sözel başka bir anlatı biçiminin yapısına bağlandığından, sinemasal dil kurulamamıştır; görsel dil kuruluk içindedir. "Metne öncelik veren biçimsel bir benzerlik amacı dolayısıyla, kamera perspektifindeki çeşitli görsel, devinimsel gerçeklerin hep birlikte yaratması gereken yaşam somutlanışı, uzam ve zaman boyutları içinde çeşitli öğelerin birliğiyle sağlanabilecek 
yürütüldüğü için onun yorumlanmasında veya eleştirilmesinde sadakat meselesi geçerliliğini korumaktadır. Palmer, sinema-yazın ilişkisini değerlendirmede yetersiz bir ölçüt olan sadakat kavramının kaynak metinle uyarlama metni arasındaki ilişkinin niteliğini açığa çıkarmada hala gözle görülür bir öneme sahip olan retorik bir güç olduğunu söyler (2004:264). Sinematik sadakate olan ilgi, başlangıçta, film uyarlamalarının büyük başarı kazanması ile artış göstermiş; film kendi popülaritesini sağladıktan sonra da bu ilgi devam etmiştir. Günümüzde ise Birleşik Devletler'de uyarlamalar, Hollywood'un yıllık üretiminin üçte birini oluşturmaktadır ve y1llar içinde en yüksek gişe getirisi olan filmler uyarlamalar olmuştur (Kranz ve Mellerski, 2008:1). Sadakat, genel bir okuyucu kitlesinin algısında küresel Hollywood film endüstrisinin yaşam kaynağıdır (Metz, 2008: 211).Ticari saiklerin dışında izleyici tepkileri açısından ve etik meselelerle bağlantılı olarak da sadakat söylemi kendine yer etmeyi sürdürür. Çok sevdiğimiz romanların bozulmadan, çarpıtılmadan uyarlanması konusundaki isteğimiz hala canlılı̆̆ını sürdürmektedir. Ayrıca, uyarlamalarda ünlü, kanonik bir yapıtın veya best-seller metnin nasıl yeniden üretildiğini, başka bir araca nasıl dönüştürüldügüüü merak etmemizden dolayı sadakat, izleyici tepkileri açısından da önemli bir meseledir. Sadakatin insanın güvenlik ve ölümsüzlük arzusunu içerdiğini söyler Kranz ve Mellerski. Görece sadık uyarlamalar, sanatsal büyüklüğün kalıcı anıtlarını üreten edebi atalarımızın veya yakın zamanlarda kanonik bir nitelik kazanan yazarlarımızın gelecekte de yaşamaya devam edeceği fikrine bağlı olarak, en muhafazakâr kültür anlayışımıza oynarlar. Sadık uyarlamalar yoluyla büyük yapıtlar başka bir araçta yaşamaya devam eder, yazılı sözcüğün ulaşacağından daha çok akla ve ruha ulaşır; böylelikle insanoğlu uygarlığın, zamanın rüzgârlarına karşı hiç değişmeyeceği düşünü kurar. Dolayısıyla film uyarlamaları söz konusu olduğunda finansal getirinin yanı sıra işin içine psikolojik tatmin de girer (Kranz ve Mellerski, 2008:2). Tüm bunların yanı sıra sadakat söyleminin uyarlama sürecinde ahlaki mihenk noktaları belirleme gereksiniminden kaynaklanan daha derin bir etik meseleden çıkamamakla da ilgisi vardır (Leitch, 2008: 206). Örneğin uyarlama bir film Dostoyevski uyarlaması olduğundan söz ediyorsa, uyarlamada Dostoyevski'yi ararız; bulamadığımızda ise filmin Dostoyevski uyarlaması olduğunu söylemesi ve Dostoyevski'nin yokluğu arasındaki çelişki etik bir mesele olarak karşımızda durur. Tüm bu nedenlerle sadakat ile ilgili tüm bu meseleler varlığını sürdürdüğü sürece sadakat söylemi de varlığını sürdürmeye devam etmektedir. Geleneksel sadakat söyleminin eleştirisi ise, bu yaklaşımın sınırlılıklarına dikkat çeker.

Her şeyden önce, olay yeri, olay örgüsü, karakterler ve temanın filmsel yeniden üretimi ve romanın biçimi hakkında önemli sorular sormasına bağlı olarak belli düzeyde evrensel gerçekler içermesinden dolayı sadakate dayalı bakma biçimini kabul etmek

orkestralama eksiktir." (1983: 495) İkinci tutum olan serbest uyarlamalarda, roman bir 'senaryo hammaddesi' olarak kullanılır; "sinema öyküsü boyutlarına indirgen"ir (Aykın, 1983:495). Burada kaynak metin esin kaynağı oluşturur; yorumlama büyük ölçüde serbesti içindedir. Her ne kadar, kimi zaman kişiler, öykünün konusu dış çizgileriyle korunsa da, kaynak yapıtın dilsel özellikleri bozulur. Bu uyarlama anlayışı temel alınarak gerçekleştiren birçok uyarlama metninde özgün metin temel yapısal özelliğini yitirmiştir. Metnin yeniden üretildiği bir diğer uyarlama anlayışı ise "romandaki nitelikleriyle yaratıcılığın sinema dilinde gerçekleştirilmeye çalışılması biçimindedir." (Aykın, 1983:496) Kaynak yapıtın temel nitelikleri korunarak onu sinema dilinde yeniden üreten bu yapıtlar, en başarılı uyarlama örnekleridir. Bu durumda roman yalnızca sinemaya öykü malzemesi sağlayan bir kaynak olmaktan çıkarak, sinema estetiğinin özelliklerine göre yeni yorumlamalara olanak sağlar; çok yönlü kullanıma örnek oluşturarak bir başka düzlemde estetik okuma alanı oluşturur. André Bazin'in deyişiyle bu tür filmler, artık, "sahnelenmiş öyküler değil, kamera ve oyuncularla yazılmış yapıtlar olmaktadır." (Aykın, 1983:496) 
zorunda olduğumuzu belirtse de bu yaklaşımın sınırlılıklarını eleştiren Stam, uyarlamaların teorik durumu/konumu veya uyarlamalara karşı analitik bir ilgiden ziyade uyarlamaların niteliği ile ilgilenen sadakat temelli geleneksel uyarlama söyleminin ve yapita körü körüne bir bağlılı̆̆ı öngören sadakat talebinin, film yapım süreçlerini ve üretim tarzı farklılıklarını ihmal ettiğini belirtir. Sinemada yazınsal uyarlamalar söz konusu olduğunda, roman gibi sözcüklere dayalı tek-kanallı bir araçtan, film gibi yalnızca yazılı ve sözlü sözcüklerle değil, aynı zamanda müzik, ses efektleri ve hareketli görüntüler içeren çok-kanallı bir araçla yapılan uyarlamalarda yazınsal sadakat ne ölçüde mümkündür? Üstelik metne aşırı sadakat, örneğin maliyet ve üretim yapıları göz önüne alındığında, gerçek film yapımı süreçlerini ihmal eder. Üretimi bireysel bir boyut taşıyan yazın, daha çok dağıtım aşamasında altyapısal sorunlarla karşı karşıya kalırken, sinema, yapımının her aşamasında bunlarla yüz yüzedir. Bunun da ötesinde her iki medyada özcü varsayımlara dayanan sadakat kavramı, romanın bir özü olduğunu ve bunun aktarılabileceğini öne sürer. Oysaki aktarılacak böyle bir öz yoktur. Olası değişik okumalara açık, çok yönlü açık bir yapı vardır karşımızda; tekil bir roman metni, sınırsız bağlamda yeniden yazılabilir ve yeniden yorumlanabilir; sonsuz olarak metinlerarası aktarımları besler ve onlardan beslenir. Metin kaç türlü okunursa o kadar sayıda uyarlaması mümkün olabilir. Üstelik neye sadık kalınacağı da açık değildir. Yönetmen her ayrıntıya sadık kalmak istediğinde zamansal kısıtları olan sinemada bunu vermek olanaklı değildir. Veya yazarın niyetine mi bağlı kalınacaktır? Oysa yazarlar genellikle kendi niyetlerini gizlerler ve karşımızda çoklu okumalara açık bir metin durmaktadır. Bu durumda özgün metne sadakatin nasıl mümkün olacağ1 sorusunu sorar Stam. Ona göre edebiyatın bireysel üretimine karş1 sinemanın işbirliği gerektiren ekip projesi olması, bütçe kısıtlarına sahip olması, yetenek, stüdyo veya yapımcı baskıları, sansür gibi meseleler ve sinemanın çok katmanlı doğası gibi iletişim aracına özgü nitelikler yüzünden filmsel uyarlama otomatik olarak farklıdır -kimi zaman belli açılardan ya da serbest bir uyarlama söz konusu olduğunda tümüyle- ve aracın değişmesinden dolayı özgündür. Film temel hikâyenin ana hatlarını özetlerse de, uyarlama metinde ortaya çıkan gerçek sonuç, birçok açıdan ölçülemez; edebiyatta her şey bir dil meselesidir; metin yeniden anlatır lakin kaynak metni bire bir yansıtmaz. Kaynak metin açık bir yapıdır, sürekli olarak sınırsız bağlamda yeniden yazılır ve yeniden yorumlanır; sonsuz olarak metinlerarası yer değiştirmeleri besler ve onlardan beslenir. Tüm bu argümanlara dayanarak Stam, filmin kaynak metne sadık olamayacağını, kaynak metin ile uyarlama arasında eşdeğerlik olmak zorunda olmadığını belirtir (Stam, 2005: 4, 15-19).

Sadakat söylemi karşısında sadakatin mümkün ve uygun olmadığını öne sürerek sadakat söylemini eleştiren ve büyük ölçüde haklılık taşıyan eleştirilere karşın uyarlama meselesinde sadakat söylemi denklemin küçük bir parçası değil, hala önem taşıyan, dikkate alınması gereken bir yan taşımaktadır. Dolayısıyla uyarlama meselelerini tümüyle kavramak istiyorsak, sadakat meselesi ile de ilgilenmek zorundayı. Halen geçerli olan önemine binaen metne sadakat yaklaşımının uyarlama çalışmalarında kullanılması kaçınılmazdır ancak bu yaklaşımın kısıtlarını da aşmak üzere. Bu iki ayrı sanat formuna özgü farklı nitelikleri göz önüne alarak, kaynak metin olan romana sadakati sinemasal uyarlamaların değerlendirilmesinde tek bir ölçüte dönüştürmek yetersiz kalmaktadır. Geleneksel sadakat söyleminin sınırlılıklarını aşma ve sadakat dişında başka meselelerle bağlantı kurma potansiyeli açısından karşıyaklaşım oldukça yol açıcıdır, sinema-edebiyat ilişkisini farklı açılardan sorunsallaştırmayı, bağlamsallaştırarak analiz etmeyi mümkün kılar ancak post-yapısalcılıktan beslenen bu perspektif, anlamın belirsizliği ve sonsuz bağlamda yeniden üretilebileceği fikri ile hem metnin 
içindeki özel anlamla hem de yazarın özgünlüğüyle bağ kurmayı güçleştirmekte, metinlere ve yazara/yönetmene dair belli tutanak noktaları geliştirme açısından sorun içermekte, metinler arasındaki açık uçlu olasılıkların sonsuz permütasyonu arasında kaybolma riski taşımaktadır. $\mathrm{Bu}$ noktada, hem sadakat yaklaşımına, hem de sadakat karşıtı yaklaşıma karşı tek yönlü eleştiri getirmekten ziyade bu farklı yaklaşımlar arasında işbirliği/uzlaşma gereksinen perspektiflerin çoğulluğuna kapı aralamak daha yol açıcı görünmektedir. Metnin yeniden üretimi belli açılardan örneğin tematik açıdan kaynak metne uygunluk taşıyabilir; romanın öyküsü/konusu, hikâyenin geçtiği yer ve zaman, biçimsel özellikler açısından hikâyeye ve ona ait detaylara sadık kalınabilir ve bu noktalarda sadakat söylemine başvurmak yerinde olabilir. Lakin sinema ve edebiyat ilişkisine ve uyarlamalarda kaynak metin dönüştüğü yapıya dair farklı meseleleri içeren bağlamsal yaklaşım da büyük önem taşımaktadır. İki ayrı aracın farklı doğasından kaynaklanan bir ortamda gerçekleşen aktarım sürecinde değişikliğin kaçınılmaz olduğu kabul edildiğinde "uyarlamayı bir dönüştürme süreci" olarak ele alabiliriz (Taylan, 1994: 89). Kaynak metnin dönüşümünü ihanet olarak görüp uyarlamaları reddetmek yerine kaynak metin ile ilişkiyi sorunsallaştırmak, ana metin ile uyarlama metin arasındaki süreklilik ve değişim noktalarını anlamlandırmak açısından metinlerararası diyalojik bir yaklaşım önem taşımaktadır.

Uyarlama sürecinin kazandığı tüm karışık görünümlere nüfuz etmek üzere metne sadakate dayalı geleneksel uyarlama söyleminin aşılmasına ve uyarlamaların değerlendirilmesinde dönüşüm metaforu ile bağlantılı olarak daha üretken bir ölçüt geliştirmeye ihtiyaç var. Uyarlamayı, bir sanat yapıtını diğerinin temsili biçimi olarak görmekten ziyade karşılıklı temasa dayanan ilişkisellik içindeki bir pratik olarak kavramak önemlidir. Bu nedenle sinema ve edebiyatın eş düzeyde önemsendiği karşılaştırmalı bir yöntem temelinde yükselecek eleştirel yaklaşımların çoğulluğu, bu ilişkiselliği kavramak açısından zenginleştiricidir. Metz, film metinleri ve onların anlamlarının belirlendiği söylemsel sistemler arasındaki metinlerarası ilişkiler ağına odaklanmak gerektiğini söyler (2008: 210). Bu noktada bu ilişkinin ele alınmasında sadakat ile ilgili meseleleri gözden çıkarmadan lakin meseleyi çok yönlü ve bağlamsal bir eksende tartışmayı, metnin yeni bir bağlamda nasıl yorumlandığı üzerinde düşünmeyi mümkün kılan metinlerarası karşılaştırmalı bir perspektif yol açıcıdır. Bakhtinyen metinlerarası bir yaklaşım bu çok yönlü boyutlar ile bağlantı kurmamıza imkân tanımaktadır.

\section{Sadakatten Metinlerarası Diyalojiye}

Dil felsefecisi, kültür ve edebiyat teorisyeni olarak Mikhail Bakhtin'in yaklaşımının en önemli yönü, metinleri yorumlamada kullandığı diyalojizm (söyleşim/söyleşimcilik) kavramıdır. Bu kavram, 60'lı yıllarda J. Kristeva'nın yorumuyla metinlerarası ilişkiler ya da metinlerarasılık kavramıla karşılanmıştır (Rifat, 2008:15). Bakhtinyen bir kavrayışla metinlerarasılık, yalnızca biçimlerin ve tekniklerin gelişimiyle sınırlı olmayan, belli bir tarihsel, toplumsal ve kültürel artalan içinde başka sözcelerle ve başka yapıtlarla ilişkisellik içinde gelişen dinamik bir olgudur (Aktulum, 1999:24). Genel olarak metinlerarası ilişkilere, özelinde sinema ve edebiyat ilişkisine ve onun en temel biçimi olan uyarlamalara dair bir yaklaşım geliştirme potansiyeli taşıyan bu metinlerarası diyalojik yaklaşımın temel önermelerinin ve kavramlarının sinema ve edebiyat ilişkisi açısından içerimleri nelerdir?

Diyalog ve Diyaloji, çokseslilik, heteroglossia, kronotop Bakhtin'in kullandığı temel kavramlar olarak öne çıkar. Diyalog; dilsel, söylemsel, toplumsal her türlü katmanlaşmanın 
ilişkilenmesini olası kılar. Her şey; farklı sesler, diller, toplumsal katmanlar arasındaki diyalog ile mümkündür. Bakhtin, sanat yapıtını "verili bir diyalog içerisinde yer alan bir yant olarak, biçemi aynı diyalogtaki diğer yanıtlarla olan karşılıklı ilişkisince belirlenen bir yanıt" olarak ele alır (2001: 50). Dilsel yapıda diyalog, sözün yapılanmasındaki kompozisyonel biçim olduğu kadar, sözcüğün tüm anlamsal ve anlatımsal katmanlarına nüfuz eden diyalojizmin de dikkate alınmasını gerektirir. Bakhtin'e göre en basit günlük konuşmadan en karmaşığına her söz edimi diyalojik yapıdadır. Söylemin diyalojik bir yönelimi vardır; her sözcük başka dönemlerin, başka seslerin kendine yer bulduğu diyalojik etkileşimsel bir alandır. "Sözcük bir diyalogda, diyaloğun içinde canlı bir yanıt olarak doğar: sözcük zaten nesnede olan yabancı bir sözcükle girdiği diyalojik etkileşimde şekillenir. Bir sözcük kendi nesnesine ilişkin bir kavramı diyalojik yoldan oluşturur." (Bakhtin,2001:56) Diyalojik yaklaşım, karşıt bakış açılarını daha yüksek bir düzeyde senteze ulaştıran bir biçimden ziyade, farklı söylemlere, farklı dillerin hiç birine ayrıcalık tanımaksızın eşit düzlemde hepsine alan açan; çoksesli, özgürlükçü, hiyerarşik olmayan, karnavalesk bir söyleşime, açık uçlu anlatıma kapı aralayan bir bakış açısına dayanır. Ona göre diyalojizm, öteki ile ilişkiyi, çoğul ve çeşitlilik taşıyan sözceleri özgül bir estetik biçime/türe tercüme eder.

Sibel Irzık, karşılıklı dışsallık ve ötekilik ilişkisinin tüm bilme biçimlerinde ve deneyim alanlarında geçerli olduğu Bakhtin'in yaklaşımını şöyle nitelendirir: “Kendini tanımlamak için gözlerini ötekine çevirmek, yabancı olanı anlatmak için kendi konumuna sıkı sıkıya bağlı kalmak." (2001: 9) Irzık, bu yaklaşımı, yalnızca insanlararası ilişkilere dair bir ilke değil, her türlü bilmenin önkoşulu olan "epistemolojik bir varsayım" olarak değerlendirir; aynı zamanda bu, farklı kavramlar ve soyutlama düzeyleri, bilmenin tüm nesneleri ve biçimleri, her türlü deneyim alanları arasında da aynı "karşılıklı dışsallık ve ötekilik ilişkileri" geçerli olduğu için, bir çözümleme yöntemidir (2001: 9). Bir şeyi anlamak için dışarlıklı olmak gerektiğini, yabancı bir kültürün kendisini derinlikli olarak ancak bir başka kültüre açabileceğini dolayısıyla anlamın derinliğinin bir başkasıyla veya yabancı bir anlamla diyaloğa girdiğinde açığa çıktığını ve böylece kapalı anlamların ve tek yönlülüğün aşılabileceğini söyleyen Bakhtin şöyle sürdürür: "Biz yabancı kültüre onun kendine sormadığı soruları yöneltiriz ve içinde kendi sorularımıza cevaplar ararız ve yabancı kültür bize yeni bakışlarını yani semantik derinliklerini ortaya sererek cevap verir. Kendi soruları olmaksızın birisi bir başkasını ya da yabancı olanı yaratıcı olarak anlayamaz. (...) Böylesi iki kültürün diyalog ilişkisi birbirine karışmak ya da birbirinin içine girmek değildir. Her ikisi de kendi birliğini açık bütünlügüüü korur ama her ikisi de karşılıklı olarak zenginleşmişlerdir." (Aktaran Akbal Süalp, 2004:60). Bakhtin'in kültürlerarası ilişkiyi tartışırken önerdiği yatay ilişki biçimi, sinema-edebiyat ilişkisine nasıl yaklaşmak gerektiğine dair bir bakış açısı sunar. Bu iki anlatı biçimini birbiri karşısında hiyerarşik olmayan bir biçimde konumlandırma; anlam derinliği içeren çoğul bir perspektif içeren bir diyalog zemini içinde sinema-edebiyat ilişkisinin sadakat dışında farklı yönlerini açığa çıkarmayı, yatay bir düzlemde kültürün olası tüm içerimleriyle bağlantı kuran bir söylem geliştirmeyi mümkün k1lar. Bireşimsel bir sanat olan sinema kendi özgüllügüünü konumlandırabilmek için diğer sanatlarla ve edebiyatla karşılıklı dışsallık ve ötekilik ilişkileri aracılığıyla diyaloğa girmek zorundadır; keza aynı şey edebiyat için de geçerlidir. Böyle bir yaklaşımla uyarlama sürecini, her sözün yazıll, sözlü, görsel tüm kültürel üretim biçimleriyle bağlantılı olmasının yarattığı çoksesli, çok dilli olanaklar içeren birer imkân alanı içinden birbiriyle söyleşen metinlerin teması olarak ele almak mümkün olur. İki metnin diyalog içine girdiği uyarlama ilişkisinde, her iki anlatı birbirinin içine karışarak ya da birbirinin içine girerek değil, kendi birliğini, açık uçlu bütünlüğünü koruyarak zenginleşir. 
Diyalojizmde, çok-dillilik (polyglossia) çok-seslilik (polyphony) ve heteroglassia (dışdilsellik) ${ }^{2}$, dilin toplumsal söylem çeşitliliğini anlatmak için anahtar kavramlar olarak öne çıkar. Farklı dillerin, farklı bakış açılarının, birçok doğrunun ve düşüncenin çatışarak içerildiği bir çokseslilik ve çok dillilik alanıdır dil ve söylem; farklı düşünceler ve seslerin birbirine açıldığı, birbiriyle söyleştiği karnavalesk bir atmosfer hâkimdir bu alana. Bakhtin'e göre çokdilliliğin dilleri birbiri ile çelişirken aynı zamanda diyalojik bir biçimde birbiri ile ilişkilidir ve kaynaşma içermeyen bir bütünlük içinde karşılıklı olarak birbirini tamamlar. Hem edebiyat hem sinema birer çokseslilik ve çok dillilik alanıdır. Her iki anlatı biçimi de diğer türleri kullanmıştır. Tarihsel gelişim sürecinde kimi türleri dışarıda bırakan, kimilerini ise kendi yapısı içine katan romanın diğer türlerin parodisi olduğunu söyler Bakhtin (2001:167). Keza film de diğer türleri ve diğer dilleri içeren bileşik bir yapıya sahiptir. Sinemanın müzik, resim, görüntü, yazı, ses unsurlarını içeren beş katmanlı doğası nedeniyle diğer sanatlarla olan organik bağı onu çok-sesli, çok-dilli özellikler açısından eşsiz bir yere koyar. Şimdiki zaman ile temas içinde oluşlarından dolayı dinamik ve değişime açık olan sinema ve romanın bu çok-dilli, çok sesli yapıları farklı tür ve biçemlerin teması için uygun bir zemin oluşturur. Uyarlama metinde içerilen çoksesli bir söylem içinde, farklı türe ait estetik değişkenler bir hâkimiyet ilişkisi içinde bulunmaksızın bir arada bulunur; farklı türler, farklı akımlar, farklı söylemler iç içe geçer ve kaynaşma içermeyen özgün bir bütünlük içinde diyalojik olarak birbiri ile ilişkili hale gelirler.

Bakhtin dillerin farklılığını ve çeşitliliğini betimlemek için kullandığı, farklı güçlerin çarpıştıkları alanı Heteroglassia (söylemlerin ayrışıp çatıştığı alan) ifadesi ile kavramsallaştırır. "Heterroglossia, belli bir ulusal dil içinde var olan biçemlerin ve söz türlerinin katmanlaşması ve çatışmaya girmesidir." (Irzık, 2001:17). Heteroglossia, yalnızca dil için değil, tüm toplumsal yaşamı kuşatan farklı dil ve söylemlerin bir arada bulunup çatışmasını ifade eden bir kavramdır (Oktay, 2009). Bakhtinci diyalojik yaklaşıma göre, roman, gerçek dünyanın temsili bir kaydı değil, bu iki dünyanın kopmaz bir biçimde birbirine bağlı olduğu, farklı dillerin ve söylemlerin içerildiği çokdilliliğe, çoksesliliğe ilişkin olan çatışmaların sahnelendiği bir formdur. Ses çeşitliliği ve heteroglossia romana girerek onu özgül kılacak bir biçim içinde örgütler ve romanı bir tür olarak farklılaştırır (Bakhtin, 2001:78). Bakhtin'in roman için kurduğu tümceyi sinema için de yinelemek mümkündür. Sinema da roman gibi "söz tiplerinin [raznorecie] toplumsal çeşitliliği aracılığıyla ve böylesi koşullar altında serpilen farklı bireysel sesler aracılığıyla temalarının tümünü, kendisinde betimlenen ve ifade edilen konuların ve fikirlerin dünyasının tümünü orkestralar." (Bakhtin, 2001:38) Bakhtin, edebiyatı kültürel bir fenomen olarak ortaya çıkaran, edebiyatın "derinlik oluşturan dizileri" dediği, yaşama ve tarihe kök salmış hem birincil hem ikincil yapıları kapsayan karmaşık ve çok yönlü bir diyalojizmden söz ederken, aynı zamanda film için de elverişli kavramlar sağlar. Bir metnin bağlamını şekillendiren diğer tüm sistemler ve diziler ile ilişkilendirmeyi sağlayan bu tarz bir diyalojizm, her sözün, edebiyattan sosyo-kültürel alana ve bilimsel araştırmalara kadar uzanan ana türlerin yanı sıra, hem sözlü hem yazılı hem basit hem karmaşık, kısa diyaloglardan günlük anlatıya kadar uzanan ikincil düzeydeki yapıları da içeren geniş bir söz türleri alanı ile olan ilişkisine dikkat çeker. Böylelikle sinemada da söz türlerine böyle bir

2 Bu kavram, Dostoyevski Poetikasıını Sorunları kitabında dış-dilsellik olarak çevrilmiş (Bahtin, 2004: 32,37). Fatma Erkman-Akerson ise, bu ifadeyi şöyle açımlamaktadır: "[poli-] çok, [hetero-] birbirinden farklı olan çift demektir, [glossia]ise, sözler bütünüdür, bir gruba özgü konuşma tarzı olarak da düşünülebilir." (Erkman- Akerson, 2010: 206) 
dillerüstü yaklaşım, sinemadaki birincil ve ikincil düzeydeki yapılar arasında bağ kurmayı mümkün kılar (Stam, 2014:212-214). Bakhtin'in bir tür tanrı gibi ele alınan yaratıcı yazara karşı, onu "kişilerarası bölge" de konumlandıran, daha mütevazi ve insan etkileşimlerine açık bir rol biçen yaklaşımı, birinin sözünün diğeri ile iç içe geçtiği "melez yapı" olarak sanatsal ifade yaklaşımına da zemin hazırlar. Bu bakış açısına göre farklı söylemlerin, yeteneklerin, tarzların, üslupların orkestrasyonu olarak görülen uyarlama da farklı medyaları, söylemleri ve işbirliklerini birleştiren "melez" bir yapı niteliğini kazanır (Stam, 2005: 9). Tıpkı roman gibi sinemada da, sanatsal bir işlemden geçerek Heteroglossia' nın metne dâhil olmasıyla, dili dolduran toplumsal ve tarihsel sesler, dile dair tüm biçimler ve yazarın/yönetmenin çağına özgü heteroglossia'ya dair toplumsal-ideolojik konumunu dışa vuran öğeler, yapılanmış bir biçemsel sistem oluşturacak biçimde örgütlenir (Bakhtin, 2001:79). Söylem ve türlerin diyaloğu olarak Heteroglossia'nın filme girmesiyle her türlü söylemsel ve türsel özelliklerin uyarlama metinde nasıl bir araya gelerek kendine özgü bir biçem ve dünya kurduğunu açımlamak mümkün k1lar.

Bakhtin'in çok-dilli ve çok-sesli olanaklar açısından zengin olan roman formu için önerdiği ve sinema için de son derece uygun olan bu metinlerarası diyalojik yaklaşım, aynı zamanda zaman-mekânsaldır (kronotop). Hem yaşamın, hem anlatıların temel koordinatlarıdır zaman ve mekân. Mekân coğrafya ile, zaman ise tarih ile bağlantı kurmayı mümkün kılar. Zaman-mekânın anlatıda devreye girmesi, tarih ve coğrafya ile ilişkilenmeyi, sosyo-kültürel ve politik bağlamsallaştırmaya olanak tanır. Ne ekonomik belirlenimci ne de biçimci olan Bakhtin, biçimi tarihsel olarak ele almayı mümkün kılan kronotop deyişini kullanır. Bakhtin, söylemde biçim ve içeriğin tek bir bütün olarak göründüğünü, amacının soyut biçimsel yaklaşım ile aynı derece soyut bulduğu ideolojik yaklaşım arasındaki kopukluğu gidermek olduğunu söyler (2001:33). Tarihsel süreçlerin metinlerarası diyaloğun çerçevesini ve sorunsallıklarını belirleme/etkileme gücü vardır. “Toplumsal olarak özgül bir ortamda tikel bir tarihsel uğrakta anlam ve şekil kazanan canlı sözce, ... toplumsal diyaloğun aktif bir katılımcısı olmaktan kaçınamaz" der Bakhtin (2001: 53). Ona göre, söylemin oluşum koşulları, yalnızca söyleyen ile dinleyen arasındaki karşılıklı etkileşime dayanan bireylerarası ilişki tarafından değil, aynı zamanda aynı kültür çerçevesi içinde üretilmiş ve üretilmekte olan tüm söylemlerle bağlantılı olarak şekillenir. Dolayısıyla hem söylemin tarih içindeki yerinin belirlenmesi hem de onun bireylerarası düzlemde toplumsal bir veri olarak alınması gereği ortaya çıkar. Bakhtin'in yöntemi, böyle bir "toplumsal tarih" temelinde "farklı söylemler arasındaki etkileşimin, karşılıklı alışverişin" incelenmesine dayanır (Yücel, 1991: 44-45). Metinlerarası ilişki, "metinlerin dünyadan ve tarihten kopuk soyut bir 'metinsellik' özelliği" ne bağlı olduğu, yalnızca bir metnin diğer metinlerin simgeleri tarafından belirlenme biçimini ifade eden, metinlerarası gönderme içeren bir metinlerarasılık değil, Bahtin' in farklı türlerin ve biçimlerin belli bir zaman-mekan içinde diyalog halinde olduğu önermesiyle bağlantılı tarihsel bir anlama sahiptir (Irzık, 2001:15). Böyle bir yaklaşımla uyarlamalarda sadakat söyleminin dışında bıraktığı diğer sanatlar ve araçlar arasındaki, yazar ve alımlayıcı arasındaki diyalojiyi içeren farklı analiz çerçeveleri kurulabilir. Kronotoplar aracılığıyla metinsel ile metin-dişı arasında çakışma olmadan belli bir mesafe içeren temas olanağı yakalanır. Böylelikle edimsel dünya ile yapıtın dünyası arasında bir köprü kurulur.

Bakhtin, zaman ve mekânın birbirinden ayrılamayacağını ifade eden kronotop kavramına, "edebiyatın biçimsel olarak kurucu kategorisi anlamını" atfeder (2001: 316). Bakhtin kuramını her ne kadar edebiyat alanından örneklerle çok özel bir anlatı türü olarak 
gördüğ̈̈ roman ile somutlaştırmış olsa da onun metindeki mekân, zaman ve kişiler arasındaki ilişkilerce belirlenen tarihsel süreci toplumsal boyutta irdelemeyi mümkün kılan koronotop kavramı, kültürün tüm alanlarında kullanılabilecek elverişli bir kavramdır. Tül Akbal Süalp'in de belirttiği üzere her söz, tüm yazılı ve sözlü kültürel üretim biçimleri, edebiyattan bilimsel metinlere kadar tüm metinler yazıldıkları, söylendikleri, gösterildikleri zaman-mekânı hem temsil eder hem de kendileri temsilin nesnesi olurlar (2004: 62). Mekânsal ve zamansal ilişkilerin iç içe geçerek öyküye ve olaylara dâhil olduğu boyutlar, roman kadar herhangi bir kültürel ürüne, filme somutluk kazandırır, ona hayat verir. "Felsefi, soyut unsurlar, toplumsal genellemeler, fikirler yerçekimine uyar gibi zaman mekâna doğru çekilirler ve orada kanlı canlı bir varlık bulurlar; böylece sanat eserinin ya da kültürel herhangi bir üretimin tahayyül eden ve ettiren gücü işler hale gelir. Zaman-mekân yapıtın yerçekimliliğini sağlayandır." (Akbal Süalp, 2004:94). Stam, Bakhtin'in zamanın somutlandığı ve hikâyenin ve tarihin hareketlerine duyarlı hale geldiği bir yer olarak roman tanımının kimi açılardan edebiyattan çok sinema için uygun olduğunu söyler çünkü edebiyat sözcüklerden oluşan sanal bir uzam içinde kendini ifade ederken sinematik zaman-mekân, gerçekçi ve belli boyutlardaki perde boyunca kendini tamamlar ve genellikle saniyede 24 kare olmak üzere tam zamanda kendini ortaya koyar. Film, zaman ve uzamın içsel ilişkiselliği düşüncesine somutluk kazandırır: "çünkü sinemada bir kayıtta yapılan her hangi bir değişiklik diğerinde de değişiklikleri gerektirir: hareket eden nesnenin daha yakın çekimi o nesnenin aşikar olan hızını arttırır, zamansal araç olan müziğin varlığı bizim uzam izlenimlerimizi farklılaştırır." (2014:214-215)

Dolayısıyla yalnızca sinemaya değil, uyarlamalara dair bir yorumsama imkânı olan Bakhtin'in kronotop kavramı, sinema ve edebiyatı ilişkilendirirken dilsel yapılarla olduğu kadar onları kuşatan toplumsal katmanla da bağlantı kurmayı mümkün kılan bir yaklaşım sunar. Böylelikle sinema ve edebiyat ilişkisine, diğer türler ve biçemlerle dizimsel ve dizinsel olarak ilişkilenme biçimini içeren yapısal unsurların yanı sıra artzamanlı ve eşzamanlı tarihsel unsurlar açısından da bakmak mümkün olur ve belli bir bağlam ekseninde uyarlamaları sorunsallaştırmanın yolu açılır. Bu yaklaşım mesela uyarlama filmde roman metninin tarihsel bağlamı değiştiğinde ne tür göstergelerin değiştiğini anlamlandırmaya vesile olur. Örneğin konusu 1960'larda geçen ve Osmanl1-Türk modernleşmesine dair meselelerin ipuçlarını içeren 1973 tarihli Yusuf Atılgan'ın Anayurt Oteli adlı romanının konusunun 1980'lere taşındığ uyarlama filmi (Ömer Kavur, 1987), 1980'lerin ikliminin zaman-mekânsal sorunsallıkları, askeri darbe ile ilgili yan anlamlar açısından düşünmek mümkün olur. Böylelikle romandan sinemaya taşınan unsurlar kadar uyarlama filmdeki fark açısından da meseleye odaklanmak uyarlamayı daha zengin anlam katmanları açısından da açımlama olanağı sunar.

Yapıt, alımlayıcılar ve dış dünya arasındaki mübadele sürecinin zaman-mekânsal olmasının yanı sıra, yapıtın da kendine özgü yaşamını oluşturan özel bir zaman-mekândan söz etmek mümkündür (Bakhtin, 2001: 328-329). Bakhtin'e göre, sanatsal imgenin edimsel dünya ile ilişkisi diyalojiktir ve yapıta veya yazara özgü farklılıklar taşıyan zaman-mekânlardan oluşur; yapıtta içerilen farklı zaman-mekânlar arasındaki ilişki arasında karmaşık diyalojik etkileşimler vardır (2001:326). Toplumsal-tarihsel, kültürel referans noktaları ile bağlantı kurmayı mümkün kılan yapıtta içerilen zaman-mekânsal boyut, temsil etme açısından güçlü bir öneme sahiptir. ${ }^{3}$ Zaman dokunulur ve görünür hale gelirken zaman-mekân anlatıdaki

3 Aslında Bakhtinci yaklaşım açısından sanatsal metnin rolü, gerçek yaşamı temsil etmek değil, farklı dillerin ve söylemlerin birbiriyle içerildiği bir çokseslilik alanı içinden çokdilliliğe ilişkin çatışmaların 
olaylara somutluk, yaşam kazandırır; olay iletilebilir ve bilgi verir, gösterilebilir hale gelir. Bu durumda zaman-mekân olayların gösterilebilirliği, temsil edilebilirliği açısından gerekli zemini oluşturur; tüm soyut öğeler zaman-mekân aracılığıyla yaşam bulup sanatın imgeleme gücünü harekete geçirir (Bakhtin, 2001:324-325). Zaman ile mekanın bağlantılı olduğuna ve bir tür içindeki farklı zamansal ve uzamsal özelliklerin buluşmasına gönderme yapan Kronotop kategorisi, metnin kendisinin zaman-mekansal ifadelerini ve öykünün içindeki zaman-mekan ilişkilerini içeren çok katmanlı bir ilişkisellik önerir. Hem romanda hem filmde bizim zaman ve mekân anlayışımızı tarihselleştirmemize imkân veren kronotop kavramını roman gibi farklı mekânsal ve zamansal göstergelerin örgütlendiği bütünlük olan filmin dünyasına tercüme ederek söylersek onun da açık veya örtük kendi kronotopları vardır ve metin-dışı kronotoplarla filme içkin olan kronotoplar arasında diyalojik bir ilişkilenme biçimi söz konusudur. Örneğin, etkisinde kaldığı Dostoyevski ile bağlantısı kurulabilecek Zeki Demirkubuz filmlerinde bir metafor olarak kullanılan kapı imgesi, metin-dışı ve metinlerarası göndermeleri olan eşik kronotopuna örnek olarak gösterilebilir. Kafka romanlarında da karşılaşılan bir imge olan kapı imgesi üzerinden yapılacak metinlerarası karşılaştırmalı bir okuma denemesi, iç-mekanların diş dünya ile ne tür bir dolayımla ilişkilendiğini gösteren farklı anlamsal olasılıkları açımlamaya vesile olabilir.

Kronotop fikriyle Bakhtin, somut zaman-mekânsal yapıların anlatısal olasılıkları, karakterleştirmeyi ve söylemi nasıl şekillendirdiği üzerinde durur. Kronotopun roman kadar sinemada da karşılığını bulması, her ne kadar anlatı teknikleri, malzemeleri farklı olsa da sinema ve edebiyatın karşılıklı etkileşimini mümkün kılan ortak yönlerin varlığı ile de ilgilidir. Bu iki anlatı biçimi olaylar, olayların tekrarlanması, olay örgüsü, karakterler ve karakterleştirme gibi kurmaca anlatılara özgü unsurlar açısından benzer yanlar taşırlar. (Sözen, 2008: 92) Edebiyatta olduğu gibi sinemada da olay, kişi, yer ve zaman arasındaki ilişkiler, zaman-mekânsal olarak inşa edilir. Zamanın, mekânın ve eylemin belli bir yapı ekseninde örgütlendiği sinemasal söylemde, anlatısal öğe kadar insan, zaman, mekân ve toplum ilişkiselliğini de içeren kronotop, öykünün belirleyici unsurları arasında yer alır. Sinemada mekân, olayların geçtiği yer, mekânın atmosferi ve onun nasıl algılandığı ile bağlantılı olarak işlev görür ve bu işlev ya alışılmış ya karşıt işleviyle anlam kazanır. Mekân gibi zaman da olayların zamanı ile karakterlerin zaman algısı arasındaki uyum/çelişki üzerine oturtulur (Sözen, 2008: 97-98). Sinemanın çok katmanlı, bileşik yapısı dolayısıyla "sinemada kronotop analizi 'görsellik ve mekân-zaman', 'ses/müzik ve mekân-zaman' gibi hem görüntüsel hem de sessel boyutun ilişkileri içinde incelenir." (Sözen, 2008: 98). Ayrıca bir roman uyarlaması söz konusu olduğunda yazınsallık ve mekân-zaman ilişkisi gibi yazınsal boyut ile alakalı ilişkiler de devreye girer.

Edebi kronotoplarla sinemasal kronotoplar arasındaki metinlerarası dönüşümün alanı son derece geniştir. Bir romanın film uyarlaması; ortamın söylemlerinin ve ideolojilerinin süzgecinden geçen mevcut türleri ve iç içe geçmiş metinleri özümseyerek ve değiştirerek, stüdyo tarzı, ideolojik yönelim, politik ve ekonomik sınırlılıklar, auterist eğilimler, karizmatik yıldızlar, kültürel değerler gibi bir dizi filtreden geçirerek, farklı bir aracın protokollerine göre bu dönüşümleri yapar. Uyarlamalar enerjileri ve yoğunlukları yeniden dağıtır, akışları ve yer değiştirmeleri teşvik eder; yazmanın dilsel enerjisi, uyarlamanın görsel-işitsel-kinetikperformatif enerjisine dönüşür. Uyarlamalar zamanlarının söylemsel enerjileri ile ilgili

sahnelenmesidir. Nitekim, ona göre iyi edebiyat, "yaşamdaki ve dildeki diyalojiye, çoksesliliğe hakkını veren edebiyattır. Roman, tam da bunu yapabilmek üzere oluşmuş bir edebi biçimdir." (Irzık, 2001: 20) 
olduğundan, üretim anında dolaşımda bulunan ideolojik eğilimlerin barometresi olurlar. Romanın sinema için her yeniden yapımı, yalnızca romanın zamanını ve kültürünü değil, fakat aynı zamanda uyarlamanın zamanı ve kültürünün de esaslarını açığa çıkarır. Bakhtin, her çağın kendi tarzına göre, geçmişin yapıtlarına yeniden vurgu yaptığını söyler. Klasik bir eserin tarihsel yaşamı, aslında, onu toplumsal ve ideolojik olarak yeniden vurgulamanın kesintisiz bir sürecidir. Bu anlamda, uyarlama, vurguyu tekrarlama işidir; yeni dizge ve söylemler yoluyla kaynak metnin yeniden vurgulanmasıdır. Her yeni dizge, söz konusu kaynak metnin belli yanlarını açığa çıkarırken, aynı zamanda yeniden vurgulama anındaki ortamın söylemleri hakkında da bir şey söyler. Romanın yeniden tasarlanması yoluyla uyarlamalar, dizgeleri ve söylemleri açığa çıkararak onlara görünür, işitilir ve algılanır bir biçim verir; onlara bir tür nesnel maddesellik kazandırır (Stam, 2005:45-46). Örneğin, edebiyat ve sinemanın eşsiz uyumunun örneklerinden biri olan 1848 tarihli Beyaz Geceler öyküsünün Visconti uyarlamasında (1957) olaylar St. Ptersburg'dan İtalya'ya taşınırken ve yalnızca insanlararası ilişkileri değil kentsel mekan ile ilişkiyi de farklılaştıran ve insanın yalnızlaşması ve yabancılaşmasını dert edinen 19. Yüzyıl modernleşme sürecine has olan nitelikler 20. yüzyılın merkezlerinden biri olan İtalya'da yeniden üretilirken, hem romanın hem filmin zaman-mekanının temel unsurları açığa çıkar. Romanın kimi yanları daha belirgin hale gelirken yeni bağlama dair ortamın söylemleri eklenir; İtalyan Yeni Gerçekçiliğine dair kimi sokak görüntüleri filme yeni katmanlar ekler. Böylelikle, metinlerdeki süreklilik noktaları kadar, yeni metnin bağlamında yeni anlamların izini sürmek mümkün olur; klasik bir eser farklı bir zaman-mekânda farklı katmanlar eklenerek yeniden üretilirken alanı genişletilmiş olur. Dostoyevski'nin klasik eseri uyarlama film ile kendi tarihsel serüvenini yaşarken yeniden vurgulanmış, yaygınlaşmış ve güncellenmiş olarak tarih içindeki yolculuğuna devam eder.

\section{Sonsöz}

Hâkim anlatı biçimi olarak romanı görüp uyarlama filmi onun simülasyonu olarak ele almak da, bunun karşısında metne sadakate dayalı söylemi tümüyle reddetmek de bir indirgemecilik biçimi olarak karşımıza çıkmaktadır. Ne geleneksel uyarlama anlayışının sorunsalı belli bir somutluk içinde tutan katı sınırları içine hapsolmadan ne de açık uçlu olasılıkların sonsuz permütasyonu arasında kaybolmadan sinema ve edebiyat ilişkisine dair tartışmaları gerekçelendirmeyi mümkün kılan belli tutanak noktaları geliştirmek zorundayız. Bu noktada sadakat söylemine onu imtiyazlandırmadan belli ölçülerde alan açmanın yerinde olduğunu savunan ancak uyarlamalarla ilgili başka meselelerle de bağ kurmamızı mümkün kılan metinlerarası bir yaklaşım önem kazanmaktadır.

Andrew, uyarlamayı, medyanın özü ya da sanat eserinin ihlali gibi savaşlardaki mücadele için değil, geldiği ve yöneldiği dünyayı anlamak için, tüm kültürel pratikleri kullandığımız gibi kullanma önerisinde bulunur. Bu dünyaların özenle incelenmesi, bundan dolayı, ciddi bir emek ve eleştirel bir anlayış gerektirir (1999: 460). Böyle bir eleştirellik için yazınsal film uyarlamaları karşısında belli katı yargıların uzağında durmalı, verili hiyerarşilerin uzağında konumlanılmalıdır; ifadelerimiz, vargılarımız daha az ahlaki olmalı, bağlamsallık ve metinlerarasılık içermelidir. Uyarlamada metne sadakat ile daha az ilgilenilmeli, kaynak metni okuma, eleştirme, yorumlama ve yeniden yazmaya dayanan diyalojik yansımalara daha çok dikkat çekilmelidir. Eğer tüm bunları yapabilirsek, diğer sanat formlarını da dikkate alan ve aralarındaki farkları anlamaya çalışan bir eleştirellik üretebiliriz (Stam, 2000:75-76). Bu durumda yine biz başarılı veya başarısız uyarlamalardan söz edeceğiz fakat bu sefer tartışma, 
sadakat kavramından ziyade "yaratıcı enerjilerin transferi”, "özgül diyalojik tepkiler" veya "okumalar", "eleştiriler", "yorumlar" veya kaynak metnin "yeniden yazımları" gibi farklı medya biçimleri ve ifade malzemeleri arasındaki farkı dikkate alan analiz biçimlerine göre inşa edilecektir (Stam, 2005: 46).

Böyle bir eleştirellik için farklı sanat türlerini her katman ve düzlemde ilişkilendirmeyi mümkün kılan Bakhtin'in diyalojik yaklaşımı, indirgeyici olmayan yaratıcı anlamaya katkıda bulunabilir. İki sanat yapıtı arasındaki temas, yalnızca estetik bir mesele değil, uyarlamayı etkileyen bir dizi toplumsal/tarihsel unsur olduğu için aynı zamanda toplumsal tarihe özgü çok yönlü bir meseledir. İç ve dış arasındaki geçirgenliğin, metinsel özellikler kadar metin-dışı faktörlerin de hesaba katılmasını gerektiren metinlerarası Baktinyen yaklaşım, uyarlamalara bakarken yalnızca metinsel bakma biçiminin -hiç kuşkusuz kendi içinde önemli ancak yetersiz olan- sınırlılıklarını aşma imkânı sunar. Sinema ve edebiyatı birbiri karşısında eş düzeyde ve diyaloğa dayalı olarak ilişkilendirmeyi; metinler arasındaki, türler arasındaki, okur, yazar ve metin arasındaki, metinsel ve metin-dışı arasındaki çok yönlü diyalojik ilişkiselliği, uyarlama metin içindeki tüm iç içe geçişleri kavrama potansiyeli taşıyan bir imkân alanı olarak duran Bakhtinyen bakma biçimi, bir yandan her bir anlatı biçimini diğeri karşısında eş-düzeyde ve kendi özgüllüğü içinde konumlandırırken sinema ve edebiyat arasında zenginleştirici bir diyaloğa vesile olabilir.

\section{Kaynakça}

Andrew, Dudley (1999). "From Concepts in Film Theory: Adaptation", F1lm Theory and Criticism, Ed:Leo Braudy, Marshall Cohen, 5.b., Oxford: Oxford Univ.Press.

Akbal Süalp, Z. Tül (2004). ZamanMekân, İstanbul: Bağlam Yay.

Aktulum, Kubilay (1999). Metinlerarası İlişkiler. Ankara: Öteki Yay.

Aykın, Cemal (1983). "Batı Toplumlarında Roman ve Sinema İlişkileri II", Türk Dili, Sayı: 383, Kasim.

Badiou, Alain (2013). Başka Bir Estetik, 2b., çev. Aziz Ufuk Kılıç, İstanbul: Metis Yay.

Bakhtin, Mikhail (2001). Karnavaldan Romana, Der. Sibel Irzık, Çev. Cem Soydemir, İstanbul: Ayrıntı Yayınları. Metis Yay.

Bahtin, Mihail M. (2004). Dostoyevski Poetikasının Sorunları, çev. Cem Soydemir, İst:

Bazin, André (1995). Çağdaş Sinemanın Sorunları, Çev. Nijat Özön, 2.b., Ankara, Bilgi Yayınevi

Bazin, André (2000). Sinema Nedir? Çev: İbrahim Şener, İst: İzdüşüm Yay.

Benjamin, Walter (1993). Pasajlar, Çev:Ahmet Cemal, İst:YKY.

Çiçekoğlu, Feride (2016). Uçurtmayı Vurmasınlar, 23. B.., İstanbul: Can Yay.

Erkman-Akerson, Fatma (2010). Edebiyat ve Kuramlar, 2. B., İstanbul: İthaki Yay.

Geloin, Ghislaine, (1988). “The Plight of Film Adaptation in France: Toward Dialogic 
Process in TheAuteur Film", Film and Literature, Ed:Wendell Aycock and Michael Schoenecker,Texas Techical Unv.Press.

Irzık, Sibel (2001). “Önsöz”, Karnavaldan Romana içinde. Mikhail Bakhtin, Der. Sibel Irzık, Çev. Cem Soydemir, İstanbul: Ayrıntı Yayınları.

Kranz, David L. ve Nancy C. Mellerski, "Introduction", In/Fidelity: Essays on Film Adaptation, ed.,

David L. Kranz ve Nancy C. Mellerski, UK, Newcastle: Cambrige Publishing, 2008.

Leitch, Thomas, "Fidelity Discorse: Its Cuse and Cure", In/Fidelity: Essays on Film Adaptation, ed., David L. Kranz ve Nancy C. Mellerski, UK, Newcastle: Cambrige Publishing, 2008.

Metz, Walter, "A Tale of Two Potters", In/Fidelity: Essays on Film Adaptation, ed., David L. Kranz ve Nancy C. Mellerski, UK, Newcastle: Cambrige Publishing, 2008.

Oktay, Ahmet (2009). “Bakhtin'le Tanışırken”, http://www.felsefeekibi.com/site/default.asp?PG=1198 (25.02.2009' da indirildi.)

Özön, Nijat (1964). “Roman ve Sinema”, Türk Dili Roman Özel Sayısı, Sayı: 154 (Temmuz 1964).

Parla Jale, (2000). Don Kişot'tan Bugüne Roman, İstanbul: İletişim Yay.

Palmer, R. Barton, (2004). “The Sociological Turn of Adaptation Studies: The Example of Film Noir", A Companion to Literature and Film, ed. Robert Stam ve Alessandra Raengo, Blackwell Yay.

Ray, Robert B., (2000). “The field of 'Literature and Film'”, Film Adaptation, Der. James Naremore, London: Athlone Press.

Rıfat, Mehmet (2008), Eleştiri Kuramcıları, İstanbul: Sel Yay.

Sözen, Mustafa (2008), “Bakhtin'in Romanda Kronotop Kavramı ve Sinema”, Akdeniz Sanat, Kasım, s. 91-107.

Stam, Robert (2000). "Beyond Fidelity: The Dialogics of Adaptation", Film Adaptation, Der: James Naremore, London: The Athlone Press.

Stam, Robert (2005). "Introduction: The Theory and Practise of Adaptation", Literature and Film: A Guide to the Theory and Practice of Film Adaptation, ed. Robert Stam ve Alessandra Raengo, Blackwell Publishing .

Stam, Robert (2014). Sinema Teorisine Giriş, İstanbul: Ayrıntı Yay.

Taylan, Cem (1994). “Sinemada Yazınsal Kaynaklardan Uyarlama Süreci”, Kuram, Kitap: 4 Ocak.

Wollen, Peter, (1989). Sinemada Göstergeler ve Anlam, Çev. Zafer Aracagök, İstanbul, Metis Yayınları.

Yücel, Tahsin (1991). Eleştirinin ABC'si. İstanbul : Simavi Yay. 